\title{
DIVERSIFICATION OF RURAL ECONOMY IN THE FUNCTION OF BALANCED REGIONAL DEVELOPMENT OF THE REPUBLIC OF SERBIA
}

\author{
Nevena Ćurčić* \\ Faculty of Sciences, Department of Geography, Tourism and Hotel \\ Management, University of Novi Sad, Republic of Serbia \\ Andrijana Mirković Svitlica \\ Faculty of Geography, University of Belgrade, Republic of Serbia
}

\begin{abstract}
Pronounced regional disparities represent one of the main features of regional development in Serbia. The regions are economically very uneven, and there are often differences within the regions themselves. The most prominent intra-regional disparity is between urban and rural areas. Rural areas are particularly vulnerable because they have experienced depopulation and economic decline for decades. This problem has been recognized and addressed in the Strategy of Agriculture and Rural Development of the Republic of Serbia from 2014-2024. One of the priority areas of implementation of the operational objectives relates to the diversification of the rural economy and the preservation of cultural and natural heritage. Due to its positive effects on GDP, employment, the balance of payments, investment and population standard, tourism is increasingly becoming an essential instrument for stimulating development, especially in those regions where employment creation through other forms of investment is challenging. Accordingly, this paper aims to present the potential of rural tourism as an endogenous factor of regional and local development through the presentation and analysis of socio-economic indicators and realized tourist traffic in the statistical regions in Serbia. Results of correlation analysis indicate a positive correlation between the number of tourists and number of employees, number of employees per 1000 inhabitants and average net earnings in NUTS 3 regions in Serbia.
\end{abstract}

Keywords: rural economy, diversification of business, tourism, regional development, disproportion, Serbia.

\footnotetext{
*nevena.curcic@dgt.uns.ac.rs
} 
49 | Diversification of rural economy in the function of balanced regional development of the Republic of Serbia

JEL classification: C49, O18, Q19, R58, Z32

\title{
DIVERZIFIKACIJA RURALNE EKONOMIJE U FUNKCIJI REGIONALNOG RAZVOJA REPUBLIKE SRBIJE
}

\begin{abstract}
Sažetak: Izražene regionalne disproporcije predstavljaju jedno od glavnih obeležja regionalnog razvoja u Srbiji. Regioni su ekonomski međusobno veoma neujednačeni, a često su prisutne razlike $i$ unutar samih regiona. Intraregionalna neujednačenost je snažno izražena na relaciji selo - grad, gde se kao posebno ugrožena izdvajaju ruralna područja koja su izložena višedecenijskim depopulacionim kretanjima i padu privredne aktivnosti. Ovaj problem je prepoznat i obrađen u Strategiji poljoprivrede i ruralnog razvoja Republike Srbije za period od 2014. do 2024. godine, u kojoj se jedno od prioritetnih područja sprovođenja operativnih ciljeva odnosi upravo na diverzifikaciju ruralne ekonomije $i$ očuvanje kulturne $i$ prirodne baštine. U radu se posebno ističe značaj turizma kao delatnosti koja, usled svojih pozitivnih efekata na BDP, zaposlenost, platni bilans, investicije i standard stanovništva, sve češce postaje ključni instrument podsticanja razvoja, posebno $u$ onim regionima u kojima je kreiranje zaposlenosti putem drugih vidova investicija teže ostvarivo. U skladu s navedenim, cilj rada je da se kroz prikaz $i$ analizu socioekonomskih indikatora $i$ ostvarenog turističkog prometa $u$ statističkim regionima u Srbiji ukaže na potencijal ruralnog turizma kao endogenog faktora regionalnog $i$ lokalnog razvoja. Rezultati korelacione analize ukazuju na pozitivnu korelaciju između broja turista i broja zaposlenih, broja zaposlenih na 1000 stanovnika i prosečne neto zarade u NUTS 3 regionima u Srbiji.
\end{abstract}

Ključne reči: ruralna ekonomija, diverzifikacija poslovanja, turizam, regionalni razvoj, disproporcija, Srbija

\section{INTRODUCTION}

Uneven regional development is one of the most significant problems in Serbia, and as such, it should occupy a central place in the development policy of our country. Nevertheless, after the attempt to define regions in the Spatial Plan of the Republic of Serbia in 1996, this issue has not been adequately treated for a long time. This problem was finally addressed in 2007 when the Strategy of Regional Development of Serbia from 2007 to 2012 (2007) was adopted. For the first time, the main priorities of the regional development were defined comprehensively and the path to their realization. This Strategy provides the basis for encouraging the balanced regional development of Serbia by raising 
regional competitiveness, reducing regional inequalities and poverty, and building regional institutional infrastructure. The Law on Regional Development from 2009 and its amendments ${ }^{\dagger}$ defined five economic-statistical NUTS-2 regions and 30 NUTS-3 areas, which confirmed the work on reducing very pronounced regional disparities, particularly apparent in the village-city relation.

Rural areas that experienced depopulation and economic decline stand out as particularly endangered. The development of tertiary activities to diversify economic activities and create additional income for rural households is one of the ways to retain and bring the population back to rural areas. As an activity that positively affects GDP, employment, the balance of payments, investments, and the standard of living, tourism has great potential as an instrument to reduce regional inequalities.

This paper aims to present the potential of rural tourism as an endogenous factor of regional and local development through the presentation and analysis of socio-economic indicators and realized tourist traffic in the statistical regions in Serbia. Accordingly, defined hypotheses will be tested using correlation analysis.

This paper consists of five parts. In addition to the introduction and conclusion, the second section provides insight into the theoretical background of sustainable rural development and tourism. In contrast, the third section presents the analysis of regional disparities and tourism indicators in Serbia. The fourth section contains the research methodology and obtained results.

\section{THEORETICAL BACKGROUND}

\subsection{SUSTAINABLE RURAL DEVELOPMENT}

Sustainable rural development is a multidimensional concept which entails synergetic harmonization of economic, social, and environmental aspects. The essence of sustainable rural development as a concept is to improve the quality of life while satisfying and strengthening socio-economic aspirations, protecting the environment and preserving natural resources. Economic growth, improvement of social conditions and preservation of natural values are equally important functions in sustainable rural development. Therefore, endogenous and exogenous resources should be used to develop these three aspects,

\footnotetext{
† see Law on Regional Development (2009), Law on Amendments to the Law on Regional Development (2010)
} 
51 | Diversification of rural economy in the function of balanced regional development of the Republic of Serbia

integrate them properly, and balance the need to preserve and improve rural specificities and diversity (Sarić, 2016; Pugliese, 2001; Long \& Van der Ploeg, 1994).

Although agriculture is still the primary activity on which sustainability is based in rural areas, its development requires a differentiated approach and activation of other activities that are not directly related to agricultural production. A gradual shift from a sectoral to a spatial focus is affecting the rural economy resulting in a progressive detachment from the exclusive production of food and fiber and in a concomitant increasing reliance on a service economy tailored to meet the new needs of urban society (Lowe, 1996). Although it is not to be expected that agricultural activities will be complementary to all activities in rural areas, agriculture can still have a pivotal and catalyzing part in meeting other equally relevant demands placed on the countryside: rural tourism, the preservation of rural landscapes and traditions, environmental education, the production of healthy, typical food. "Thus, the diversification of the rural economy and agricultural pluriactivity are important developing trends, which can be strategically devised to transform urban-rural geographical adjacency into sustainable multifunctional linkages" (Pugliese 2001, p.114).

\subsection{TOURISM AND RURAL DEVELOPMENT}

The idea of the positive impact of tourism on rural development by the OECD Tourism Committee, supported by the positive effects of global tourism, emerged in the late 1980s. Support to rural areas that have been exposed to decades of population loss and declining incomes in the agricultural sector (households) is seen through the creation of adequate tourism strategies that can support development in rural areas as a complementary activity. This attitude is explained by the fact that during the period of the greatest devastation of rural areas, tourist activity at the global level experienced a tremendous expansion, with the number of tourists and the income from their travels increasing from year to year. For this reason, tourism is considered an endogenous factor that can stimulate regional and local development and generate economic growth. Many authors believe that tourism development can improve the economic situation in rural areas (Hall \& Brown, 2000; Ploeg \& Renting, 2000; Viljoen \& Tlabela, 2007; Cabrini, 2002; Blaine \& Golan, 1993; Dernoi, 1991; Mortan, 2006). Tourism can have a significant impact on the economic, social, functional and physiognomic structure of rural areas (Pavlović \& KovačevićBerleković, 2018). 
One of the first definitions of rural tourism was proposed by the European Commission in 1986: "Rural tourism is a broad concept which covers not only farm tourism or agri-tourism - i.e., accommodation provided by farmers - but all tourist activities in rural areas. This type of tourism is attractive to city dwellers in search of restful country holidays and, if better known, could expand and contribute to a better seasonal and geographical distribution of tourism (since it is less dependent on the weather than is mass tourism)" (EC, 1986, p.10).

In essence, we can say that rural tourism should be (OECD, 1994, p.14):

- located in rural areas;

- based on the specific characteristics of rural areas - small businesses, open space, contact with nature, traditional societies and traditional activities;

- rural in scope - in terms of buildings and settlements - which means mostly smaller in scope;

- traditional character, slow and sustainable growth, connected with local families, all for the long-term well-being of the area;

- sustainable - its development should help preserve the specific rural character of the environment and be sustainable in the use of resources. Rural tourism should be seen as a potential means of conservation and sustainability, rather than a means of urbanization and development, and

- diverse, representing a complex pattern of the rural environment, economy and history.

The following is a classification of vacations (trips) in predominantly rural and urban areas, with a broad transitional category (Table 1). These vacations are associated with staying in nature and increased sports and recreational activities. 
53 | Diversification of rural economy in the function of balanced regional development of the Republic of Serbia

Table 1

Tourist activities by the type of area

\begin{tabular}{|c|c|c|}
\hline $\begin{array}{l}\text { Holidays which are } \\
\text { usually specifically rural }\end{array}$ & $\begin{array}{c}\text { Holidays which may } \\
\text { be rural or urban/resort } \\
\text { based }\end{array}$ & $\begin{array}{l}\text { Holidays which are usually } \\
\text { specifically urban/resort } \\
\text { based }\end{array}$ \\
\hline Walking & Swimming & City sightseeing \\
\hline Climbing & $\begin{array}{l}\text { Low/medium intensity } \\
\text { beach holidays }\end{array}$ & Shopping \\
\hline $\begin{array}{l}\text { "Adventure" holidays/wilderness } \\
\text { holidays }\end{array}$ & $\begin{array}{l}\text { Medium intensity downhill } \\
\text { skiing }\end{array}$ & High-intensity beach holidays \\
\hline Canoeing & $\begin{array}{l}\text { Sports requiring man-made } \\
\text { infrastructure of a semi- } \\
\text { natural type, e.g., golf }\end{array}$ & $\begin{array}{l}\text { High-intensity downhill } \\
\text { skiing }\end{array}$ \\
\hline Rafting & Cuisine-based holidays & $\begin{array}{ll}\text { Urban } & \text { heritage/culture } \\
\text { holidays } & \\
\end{array}$ \\
\hline Cross-country skiing & General heritage holidays & Zoological gardens \\
\hline Snow-shoe tours & Conservation holidays & Health resorts \\
\hline $\begin{array}{l}\text { Low intensity } \\
\text { downhill skiing }\end{array}$ & Educational holidays & Industrial tourism \\
\hline $\begin{array}{l}\text { Nature study in outdoor settings, } \\
\text { including } \\
\text { photography etc. }\end{array}$ & Cultural festivals & $\begin{array}{l}\text { Major } \\
\text { conferences/conventions }\end{array}$ \\
\hline Hunting & Craft holidays & $\begin{array}{l}\text { Entertainment } \\
\text { holidays/gambling }\end{array}$ \\
\hline Cycling/Cycle touring & Camping & Resort holidays \\
\hline Horse riding & Sightseeing/Touring & $\begin{array}{lr}\text { Sports requiring } & \text { man-made } \\
\text { infrastructure, } & \text { e.g., } \\
\text { international } & \text { arena-based } \\
\text { events } & \end{array}$ \\
\hline Landscape appreciation & $\begin{array}{l}\text { Small/medium-sized } \\
\text { conferences/conventions }\end{array}$ & \\
\hline Rural heritage Studies & Sailing/cruising & \\
\hline Small town/village touring & Sea angling & \\
\hline $\begin{array}{l}\text { Relaxation holidays requiring a } \\
\text { rural milieu }\end{array}$ & & \\
\hline $\begin{array}{l}\text { Small scale } \\
\text { conventions/conferences }\end{array}$ & & \\
\hline Rural festivals & & \\
\hline River and canal angling & & \\
\hline $\begin{array}{l}\text { Sports requiring natural settings, } \\
\text { e.g. orienteering }\end{array}$ & & \\
\hline
\end{tabular}

Note. Taken from Tourism strategies and rural development. OECD (1994), Paris, p.14. 


\section{REGIONAL DISPARITIES AND RURAL TOURISM IN THE REPUBLIC OF SERBIA}

According to Eurostat urban-rural classification, rural areas occupy about $80 \%$ of the territory of the Republic of Serbia, with more than $60 \%$ of the total population living in these rural areas (Statistical Office of the Republic of Serbia, 2020). The transition and economic downturn, which left significant consequences for the entire country, had a particularly negative impact on rural areas. The process of demographic depopulation, already started after World War II, was further accelerated by current events. This resulted in an aging population, poorer qualification structure, low productivity resulting from agriculture as the dominant activity, high unemployment rates, and a low share of rural areas in the country's total GDP. One way to retain and bring the population to rural areas is to develop the tertiary sector to diversify economic activities and create additional income for rural households. Analyzing natural and anthropogenic tourist resources on the territory of Serbia, it is concluded that it has significant potential for the development of rural tourism. Wealth, preservation and attractiveness of natural resources, a large number of traditional agricultural households, the gradual growth of living standards of the local population, as well as the growing interest of the international tourism market in rural tourism experiences, are a fairly solid basis for rural tourism development throughout Serbia, especially in its southwestern and southeastern part. Among the most characteristic tourist products of rural tourism in Serbia are agro tourism and rural experience in rural areas in different locations (western and eastern Serbia), eco-rural tourism (individual destinations throughout Serbia), combined forms of rural tourism and special interests (cycling tours) by rural areas, visits to local rural events (Manić, 2014, p.27). However, despite the rich resource base, it seems that rural tourism in Serbia has not reached the expected level of development. Non-recognition of the potential of rural tourism by the local population and local authorities, lack of funding and encouragement of entrepreneurial and innovative activities, turning to other mass forms of tourism, underdeveloped environmental awareness and fragmented rural estates are just some of the factors influencing poor development of rural tourism. Although Serbia possesses a diversified structure of attractiveness, this structure is not accompanied by an adequate profile of tourist products (Todorović \& Bjeljac, 2009, p.455). The tourist product is largely limited by the insufficient knowledge and experience of the service providers and lack of funding, which have a limiting effect on organizing the service at a higher qualification level (Ćurčić, Mirković Svitlica, Brankov, Bjeljac, Pavlović \& Jandžiković, 2021; Bjeljac, Brankov, Ćurčić \& Milanović 
55 | Diversification of rural economy in the function of balanced regional development of the Republic of Serbia

Pešić, 2020). Rural tourism is becoming the main tool for revitalizing and mobilizing the rural environment with an emphasis on the sustainability of the economy and society (Ćurčić, Bjeljac, Terzić \& Mirković, 2018; Vujko, Petrović, Dragosavac, Curčić \& Gajić, 2017). The positive effects of rural tourism are realized by increasing local production and the protection of rural areas.

Table 2 and Table 3 below present socio-economic indicators and realized tourist traffic in statistical regions in Serbia. These tables emphasize regional disparities and the potential of rural tourism as an endogenous factor of development in Serbia. For the purposes of this paper, the methodology of the European Commission for the urban-rural classification of NUTS-3 regions was applied. ${ }^{*}$

Table 2 shows the basic socio-economic indicators of the NUTS 3 regions in Serbia. Based on the analysis of the data, we can conclude that there is a pronounced polarization in development between Belgrade and the rest of the country. In addition to Belgrade, which according to the classification is the only urban region, the district Južnobačka, classified as an intermediate region, stands out in terms of the number of employees and average net earnings. Rural regions are traditionally at the back of all development factors, and the basic task of development policy should be to address this burning issue.

\footnotetext{
¥ see http://ec.europa.eu/eurostat/statistics-explained/index.php/Urban-rural_typology
} International Journal of Economic Practice and Policy, 18(1), 48-63 
Table 2

Socio-economic indicators of NUTS 3 regions in Serbia

\begin{tabular}{|l|r|r|r|r|r|r|}
\hline Region & $\mathbf{1}$ & $\mathbf{2}$ & $\mathbf{3}$ & $\mathbf{4}$ & \multicolumn{1}{|l}{$\mathbf{5}$} & \multicolumn{1}{|c|}{$\mathbf{6}$} \\
\hline REPUBLIC OF SERBIA & 88499 & 6945235 & 2173135 & 313 & 3,8 & 54919 \\
\hline Urban regions & & & & & & \\
\hline Beogradski & 3234 & 1694056 & 631314 & 373 & 3,9 & 68140 \\
\hline Intermediate regions & & & & & & \\
\hline Južnobački & 4026 & 618829 & 210228 & 340 & 3,9 & 55618 \\
\hline Nišavski & 2728 & 360494 & 108798 & 302 & 3,9 & 48963 \\
\hline Rural regions & & & & & & \\
\hline Zapadnobački & 2488 & 171054 & 47272 & 276 & 3,3 & 46924 \\
\hline Južnobanatski & 4246 & 277393 & 79814 & 288 & 3,3 & 52278 \\
\hline Severnobanatski & 2328 & 135453 & 38507 & 284 & 2,7 & 49138 \\
\hline Severnobački & 1784 & 178294 & 55807 & 313 & 3,8 & 50291 \\
\hline Srednjobanatski & 3257 & 173873 & 52306 & 301 & 2,5 & 50879 \\
\hline Sremski & 3485 & 297197 & 93812 & 316 & 2,7 & 48752 \\
\hline Zlatiborski & 6140 & 265638 & 77740 & 293 & 5,7 & 46800 \\
\hline Kolubarski & 2474 & 162165 & 51364 & 317 & 2,9 & 49951 \\
\hline Mačvanskai & 3270 & 277560 & 79634 & 287 & 2,8 & 45748 \\
\hline Moravički & 3016 & 198490 & 63609 & 320 & 4,1 & 47271 \\
\hline Pomoravski & 2614 & 197361 & 50658 & 257 & 3,8 & 44676 \\
\hline Rasinski & 2668 & 221672 & 61500 & 277 & 3,8 & 44707 \\
\hline Raški & 3923 & 304478 & 72479 & 238 & 6 & 44304 \\
\hline Šumadijski & 2388 & 281277 & 85489 & 304 & 3,8 & 50425 \\
\hline Borski & 3507 & 111152 & 30293 & 273 & 3,9 & 54977 \\
\hline Braničevski & 3857 & 165635 & 43561 & 263 & 3,8 & 51362 \\
\hline Zaječarski & 3624 & 106100 & 26239 & 247 & 4,8 & 45971 \\
\hline Jablanički & 2770 & 198740 & 51941 & 261 & 3 & 42518 \\
\hline Pirotski & 2761 & 83699 & 23902 & 286 & 4,1 & 50614 \\
\hline Podunavski & 1250 & 184994 & 51774 & 280 & 2,8 & 51125 \\
\hline Pčinjski & 3520 & 196431 & 46617 & 237 & 4 & 44468 \\
\hline Toplički & 2231 & 83200 & 23137 & 278 & 2,4 & 44688 \\
\hline & & & & & & \\
\hline
\end{tabular}

Note. Data taken from Municipalities and regions in Serbia, 2020. Beograd: Statistical Office of the Republic of Serbia (2020), taken from http://webrzs.stat.gov.rs

Legend. 1- Area km²; 2- Population; 3- Number of employees; 4- Number of employees per 1000 inhabitants; 5- Employees in accommodation and food services \%; 6- Average net earnings. 
57 | Diversification of rural economy in the function of balanced regional development of the Republic of Serbia

Table 3

Tourism indicators of NUTS 3 regions in Serbia

\begin{tabular}{|c|c|c|c|c|}
\hline Region & $\begin{array}{c}\text { Number of } \\
\text { tourists }\end{array}$ & $\begin{array}{l}\text { Number of } \\
\text { tourists \% }\end{array}$ & $\begin{array}{l}\text { Number } \\
\text { of nights }\end{array}$ & $\begin{array}{c}\text { Number of } \\
\text { nights \% }\end{array}$ \\
\hline REPUBLIC OF SERBIA & 3689983 & 100 & 10073299 & 100 \\
\hline \multicolumn{5}{|l|}{ Urban regions } \\
\hline Beogradski & 1258348 & 34,1 & 2696832 & 26,8 \\
\hline \multicolumn{5}{|l|}{ Intermediate regions } \\
\hline Južnobački & 253054 & 6,9 & 502893 & 5,0 \\
\hline Nišavski & 141537 & 3,8 & 249626 & 2,5 \\
\hline \multicolumn{5}{|l|}{ Rural regions } \\
\hline Zapadnobački & 24944 & 0,7 & 98398 & 1,0 \\
\hline Južnobanatski & 35085 & 1,0 & 140379 & 1,4 \\
\hline Severnobanatski & 34393 & 0,9 & 155491 & 1,5 \\
\hline Severnobački & 106800 & 2,9 & 187548 & 1,9 \\
\hline Srednjobanatski & 23247 & 0,6 & 77301 & 0,8 \\
\hline Sremski & 84134 & 2,3 & 222334 & 2,2 \\
\hline Zlatiborski & 394143 & 10,7 & 1254020 & 12,4 \\
\hline Kolubarski & 70466 & 1,9 & 268186 & 2,7 \\
\hline Mačvanskai & 67227 & 1,8 & 266519 & 2,6 \\
\hline Moravički & 92623 & 2,5 & 352171 & 3,5 \\
\hline Pomoravski & 27362 & 0,7 & 65774 & 0,7 \\
\hline Rasinski & 58262 & 1,6 & 219629 & 2,2 \\
\hline Raški & 453460 & 12,3 & 1534221 & 15,2 \\
\hline Šumadijski & 96142 & 2,6 & 212946 & 2,1 \\
\hline Borski & 88392 & 2,4 & 208655 & 2,1 \\
\hline Braničevski & 53319 & 1,4 & 133475 & 1,3 \\
\hline Zaječarski & 178848 & 4,8 & 759748 & 7,5 \\
\hline Jablanički & 34579 & 0,9 & 116502 & 1,2 \\
\hline Pirotski & 28720 & 0,8 & 48231 & 0,5 \\
\hline Podunavski & 21704 & 0,6 & 31957 & 0,3 \\
\hline Pčinjski & 31678 & 0,9 & 89386 & 0,9 \\
\hline Toplički & 31516 & 0,9 & 181077 & 1,8 \\
\hline
\end{tabular}

Note. Data taken from Municipalities and regions in Serbia, 2020. Beograd: Statistical Office of the Republic of Serbia (2020), taken from http://webrzs.stat.gov.rs

From Tables 2 and 3 we can see that the tourist activity in Serbia is spatially unevenly distributed. However, the distribution of tourist activity among the districts still only partially coincides with their position in the overall economic, 
educational and demographic development. Table 3 (on the total number of tourists and the number of overnight stays) shows that tourist activity in Serbia is concentrated in three areas - Belgrade, Zlatibor and Raška. The cumulative share of these three areas in the total number of tourists in Serbia is $57.1 \%$, namely Belgrade $34.1 \%$, Zlatibor 10.7 and Raška $12.3 \%$. The situation with the number of overnight stays is similar. $54.4 \%$ of the total number of overnight stays in Serbia is realized in the mentioned areas, with the share of Belgrade decreasing at the expense of Zlatibor and Raška, where on average tourists stay longer - which is characteristic for mountain and spa tourism represented mainly in these areas.

\section{RESEARCH METHODOLOGY AND RESULTS}

\subsection{METHODOLOGY}

In order to analyze the significance of tourism activities for regional development, the following hypotheses are defined:

Hypothesis $1\left(\mathbf{H}_{1}\right)$ : There is a positive, significant correlation between the number of tourists and the number of employees in NUTS 3 regions in Serbia.

Hypothesis $2\left(\mathbf{H}_{2}\right)$ : There is a positive, significant correlation between the number of tourists and the number of employees per 1000 inhabitants in NUTS 3 regions in Serbia.

Hypothesis $3\left(\mathbf{H}_{3}\right)$ : There is a positive, significant correlation between the number of tourists and average net earnings in NUTS 3 regions in Serbia.

Research is based on correlation analysis, and secondary data from the Statistical Office of the Republic of Serbia and publication Municipalities and regions in Serbia, 2020, were used. The data is shown in Table 2 and Table 3. The Statistical Package for Social Sciences, IBM SPSS 20.0 Statistics, was used for data processing.

\subsection{RESULTS}

The tables below show correlation analysis results, where the correlation coefficient indicates the strength of the relationship between observed variables. 
59 | Diversification of rural economy in the function of balanced regional development of the Republic of Serbia

Table 4

Correlation between number of tourists and number of employees

\begin{tabular}{|ll|r|r|}
\hline & Pearson Correlation & \multicolumn{1}{c|}{$\begin{array}{c}\text { Number of } \\
\text { tourists }\end{array}$} & \multicolumn{1}{c|}{$\begin{array}{c}\text { Number of } \\
\text { employees }\end{array}$} \\
\hline Number of tourists & Sig. (2-tailed) & 1 & $.911^{* *}$ \\
& $\mathrm{~N}$ & 25 & .000 \\
& Pearson Correlation & $.911^{* *}$ & 25 \\
Number of employees & Sig. (2-tailed) & .000 & 1 \\
& $\mathrm{~N}$ & 25 & 25 \\
\hline
\end{tabular}

Note. Authors calculation. ${ }^{* *}$ Correlation is significant at the 0.01 level (2-tailed).

Based on the results in Table 4, it can be concluded that there is a positive, significant correlation between the number of tourists and the number of employees in NUTS 3 regions in Serbia (Hypothesis 1 is supported), and that link between these variables is very strong $(\mathrm{r}=0.911 ; \mathrm{p}=0.000)$.

Table 5

Correlation between number of tourists and number of employees per 1000 inhabitants

\begin{tabular}{|ll|r|r|}
\hline & \multicolumn{1}{c|}{$\begin{array}{c}\text { Number of } \\
\text { tourists }\end{array}$} & $\begin{array}{c}\text { Number of } \\
\text { employees per } \\
\mathbf{1 0 0 0} \text { inhabitants }\end{array}$ \\
\hline Number of tourists & Pearson Correlation & 1 & $.499^{* * *}$ \\
& Sig. (2-tailed) & 25 & .000 \\
& $\mathrm{~N}$ & $.499^{* *}$ & 25 \\
Number of employees per & Pearson Correlation & .000 & 1 \\
$\mathbf{1 0 0 0}$ inhabitants & Sig. (2-tailed) & 25 & 25 \\
\hline
\end{tabular}

Note. Authors calculation. ${ }^{* *}$ Correlation is significant at the 0.01 level (2-tailed).

Data presented in Table 5 show a positive, significant correlation between the number of tourists and the number of employees in NUTS 3 regions in Serbia (Hypothesis 2 is supported), but the correlation is moderate $(\mathrm{r}=0.499 ; \mathrm{p}=$ $0.000)$. 
Table 6

Correlation between number of tourist and average net earnings

\begin{tabular}{|ll|r|r|}
\hline & & $\begin{array}{c}\text { Number of } \\
\text { tourists }\end{array}$ & \multicolumn{1}{c|}{$\begin{array}{c}\text { Average net } \\
\text { earnings }\end{array}$} \\
\hline Number of tourists & Pearson Correlation & 1 & $.665^{* *}$ \\
& Sig. (2-tailed) & 25 & .003 \\
& $\mathrm{~N}$ & $.665^{* * *}$ & 25 \\
Average net earnings & Pearson Correlation & .003 & 1 \\
& Sig. (2-tailed) & 25 & 25 \\
\hline
\end{tabular}

Note. Authors calculation. ${ }^{* *}$ Correlation is significant at the 0.01 level (2-tailed).

Data presented in Table 6 show a positive, significant correlation between the number of tourists and net earnings in NUTS 3 regions in Serbia (Hypothesis 3 is supported), with moderate to strong correlation $(\mathrm{r}=0.665 ; \mathrm{p}=0.003)$.

Although the coefficient of correlation does not show a causal relationship, results from the tables above support the assumption that tourism activities positively affect the economy of regions in Serbia. Also, while significant, these indicators do not fully reflect the importance of tourism for developing these regions and areas, given its comprehensive impact on many sectors and the characteristic spillover effect.

\section{CONCLUSION}

Rural tourism is a significant factor in the development of rural regions. Agriculture as the main activity of the population in rural areas is usually not developed enough to be the only factor in employment. In the Strategy of Agriculture and Rural Development of the Republic of Serbia for the period 2014-2024, one of the priorities within which the operational goals of the Strategy are implemented is the diversification of the rural economy and the preservation of cultural and natural heritage, areas that are complementary to tourism. The diversification of the rural economy provides additional sources of income to rural households and provides the rural population with access to more diverse services, thus increasing their quality of life.

The pronounced polarization and growing regional inequalities are the basic features of the regional development of Serbia, which is confirmed by data 
61 | Diversification of rural economy in the function of balanced regional development of the Republic of Serbia

shown in Tables 2 and 3. In accordance with the pronounced regional disparities according to the overall level of development, the tourist activity in Serbia is also spatially unevenly distributed. However, the distribution of tourist activity among the districts still only partially coincides with their position in the overall economic, educational and demographic development. Correlation analysis results support the defined hypotheses and indicate a positive correlation between the number of tourists and number of employees, number of employees per 1000 inhabitants and average net earnings in NUTS 3 regions in Serbia.

The future development of rural areas in Serbia should further strengthen the diversification of the rural economy based on knowledge and the growth of activities of local and regional communities. National support and investment in resources can increase the tourism potential of rural regions, which will create a sound basis for starting new businesses. Diversification in tourism development and related services should be only one of the elements of strengthening the rural economy and its market recognition.

\section{REFERENCE}

Bjeljac, Ž., Brankov, J., Ćurčić, N., \& Milanović Pešić, A. (2020). Traditional sports and games in the function of sustainable development of rural tourism - a case study of "Vojvodjanska olimpijada starih sportova" (Bačko Gradište, Serbia). In Innovative Aspects of the Development Service and Tourism (13-18). Stavropol, Russia: Stavropol State Agrarian University, Faculty of Social and Cultural Service and Tourism, SEQUOIA.

Blaine, T., \& Golan, M. (1993). Demand for Rural Tourism: An Exploratory Study. Annals of tourism research, 20, 770-773.

Cabrini, L. (2002). Rural tourism in Europe: Experiences and perspectives. Retrieved from

http://www.worldtourism.org/regional/europe/PDF/rural_en.pdf

Ćurčić, N., Bjeljac, Ž., Terzić, A., \& Mirković, A. (2018) Importance of tourism for sustainable rural development. In: Sustainable development of tourism market: international practices and Russian experience (36-41). Stavropol, Russia: Stavropol State Agrarian University, Faculty of Social and Cultural Service and Tourism, SEQUOIA.

Ćurčić, N., Mirković Svitlica, A., Brankov, J., Bjeljac Ž., Pavlović, S., \& Jandžiković, B. (2021). The Role of Rural Tourism in Strengthening the 
Sustainability of Rural Areas: The Case of Zlakusa Village. Sustainability, 13(12), 6747.

Dernoi, I. (1991). About Rural and Farm Tourism. Tourism Recreation Research, 16(1), 3-6.

European Commission (1986). Community Action in the field of tourism. Commission communication to the Council. COM (86) 32 final, 5 February 1986. Bulletin of the European Communities, 4/86, 10.

Hall, D., \& Brown, F. (2000). Tourism in peripheral areas. Clevedon: Channel View.

Long, A., \& Van der Ploeg J. D. (1994). Endogenous development: Practices and perspectives. In Born from within. Practice and perspectives of endogenous rural development (1-6). Assen: Van Gorcum.

Lowe, P. (1996). Blueprint for the rural economy. In The rural economy and the British countryside (187 - 202). London: Earthscan.

Law on Regional Development. Official Gazette of the RS, No 51 (2009).

Manić, E. (2014). Održivi ruralni turizam kao factor razvoja rurlanih područja: primer Srbije. Acta geographica Bosniae at Herzegovinae, 1(1), 23-34.

Mortan, M. (2006). Agritourism Rural Development Public Administration. Transylvanian Review of Administrative Sciences, 16, 101-105.

OECD (1994). Tourism strategies and rural development. Paris, p.14. Retrieved from https://www.oecd.org/cfe/tourism/2755218.pdf

Pavlović, N., \& Kovačević-Berleković, B. (2018). Turizam kao pokretač razvoja ruralnih prostora - studija slučaja jugoistočne Bačke. Škola biznisa, 1/2018, 105-122.

Ploeg, J. D., \& Renting, H. (2000). Impact and potential: A comparative Review of European Rural Development Practice. Sociologia Ruralis, 40(4), 529543.

Pugliese, P. (2001). Organic Farming and Sustainable Rural Development: A Multifaceted and Promising Convergence. Sociologia Ruralis, 41(1), 112-130.

Statistical Office of the Republic of Serbia (2020). Municipalities and regions in Serbia, 2020. Beograd. Retrieved from https://publikacije.stat.gov.rs/G2020/PdfE/G202013047.pdf 
63 | Diversification of rural economy in the function of balanced regional development of the Republic of Serbia

Sarić, R. (2016). Održivi ruralni razvoj - koncept i merenje. Beograd: Ekonomski fakultet. Retrieved from https://nardus.mpn.gov.rs/handle/123456789/7508

Spatial Plan of the Republic of Serbia (1996). Official Gazette of the RS, 13/1996.

Strategy of Agriculture and Rural Development of the Republic of Serbia for the period 2014-2024 (2014). Official Gazette of the RS, 85/2014.

Strategy of Regional Development of Serbia for the period from 2007 to 2012 (2007). Beograd: Republički zavod za razvoj. Retrieved from http://www.gs.gov.rs/english/stampa-eng/strategije-vs.html

Todorović, M., \& Bjeljac, Ž. (2009). Rural tourism in Serbia as a concept of development in undeveloped regions. Acta geographica Slovenica, 49(2), 453-473.

Viljoen, J., \& Tlabela, K. (2007). Rural tourism development in South Africa: Trends and challenges. Cape Town, South Africa: Human Science Research Council Press (HSRCP). Retrieved from http://www.hsrcpress.ac.za

Vujko, A., Petrović, M. D., Dragosavac, M., Ćurčić, N., \& Gajić, T., (2017) The linkage between traditional food and loyalty of tourists to the rural destinations. TEME, 41(2), 475-487.

Delivered: 01.11.2021.

Accepted: 06.12.2021. 